\title{
Orphan Works Situation Under Canadian Copyright Act
}

\author{
Bzhar Abdullah Ahmed \\ Lecturer and Head of Higher Education Unit at Faculty of Law, Political Science and Management, Soran \\ University
}

\begin{abstract}
This article examines the orphan works solution under the Canadian Copyright Act. This article introduces the type of solution adopted by the Canadian Copyright Act. The author undertake a qualitative approach to a thorough investigation that discloses that Canada has adopted centrally granted licensing model which enables a public body to issue licenses for users of orphan works. The author also revealed that under the Canadian system a prospective user is required to carry out a reasonably diligent search prior to using orphan works. It is understood that the type of solution adopted by the Canadian law may not function well at the moment, due to technological advancements that allow public libraries and other public institutions to digitise the whole collections that they own. However, compulsory licenses model could be considered a barrier before such institutions to have all their collections digitised, therefore, it is preferred for the Canadian law to adopt extended collective licenses model in addition to the compulsory licensing model.
\end{abstract}

Keywords: orphan works, centrally granted licenses, license, section 77 .

DOI: $10.7176 / \mathrm{JLPG} / 95-12$

Publication date:March $31^{\text {st }} 2020$

\section{Introduction}

Authors are provided with the exclusive rights under which nobody is permitted to utilise their work without prior permission. Nevertheless, utilisers might encounter a situations, known as orphan works, in which the copyright holder is unidentified or untraceable, that makes it difficult or even impossible for the utiliser to obtain the license. Orphan works are copyrighted works whose owners are difficult or impossible to identify and lor locate after a diligent search has been carried out. ${ }^{1}$

Canada has provided a solution to the problem of orphan works since 1988 under the Canadian Copyright Act of 1985. Although the original Canadian Copyright Act of 1985 did not initially contain a solution to the problem of orphan works, it did so by amending the Act in $1988 .^{2}$ The Canadian Copyright Act calls works orphans if they have 'owners who cannot be located'. Under section 77 of the Canadian Copyright Act, in the case of the failure of the prospective user to locate the copyright holder of a work, the Copyright Board of Canada may grant a licence to the user in order to make use of the work. ${ }^{3}$ However, the Board grants authorisation only if it is satisfied that the prospective user has made reasonable efforts to trace the copyright owner but was unable to do so, despite that effort. If the Board is satisfied that the prospective user has made the required effort, it can grant a nonexclusive licence permitting the user to make use of the work under the conditions set by the Board, such as those relating to licence fees, expiration time and type of use. ${ }^{4}$

The Copyright Board of Canada is given wide discretion, which has led to a number of legal and practical issues. In respect of paying royalties, the Board can require the user to pay either at the time of locating the copyright holder or instantly to a collecting society that represents the copyright owners. ${ }^{5}$ It has been demonstrated that among the terms and conditions set by the Copyright Board of Canada, those regarding price and payment have been the most difficult issues. ${ }^{6}$ Wide discretion is also vested in the Canadian Copyright Board regarding issuing a licence if there is uncertainty about whether the required work is still under copyright protection or not, and the Board also has discretion with regard to denying an application, provided the issuance of the licence is denied reasonably. The Canadian Copyright Board has also to act reasonably in respect to setting the terms and conditions of a licence. ${ }^{7}$

\footnotetext{
${ }^{1}$ Bzhar Abdullah Ahmed and Kameran Hussein Al-Salihi, 'Proliferation of the problem of orphan works across the world' (2019) 22 The Journal of World Intellectual Property 419.

${ }^{2}$ Marcella Favale and others, 'Copyright, and the Regulation of Orphan Works: A Comparative Review of Seven Jurisdictions and a Rights Clearance Simulation' (UK Intellectual Property Office, July 2013) 32.

${ }^{3}$ Canadian Copyright Act 1985 last amended on 19 June 2017, s. 77.

${ }^{4}$ British Screen Advisory Council, 'Copyright and Orphan Works: A Paper Prepared for the Gowers Review' (August 2006) 10.

${ }^{5}$ Giuseppe Golangelo and Irene Lincesso, 'Law Versus Technology: Looking for a Solution to the Orphan Works' Problem' (2012) 20 International Journal of Law and Information Technology 178, 200.

${ }^{6}$ Bingbin Lu, 'The Orphan Works Copyright Issue: Suggestions for International Response' (2013) 60 Journal, Copyright Society of the USA $255,265$.

7 Jeremy De Beer and Mario Bouchard, 'Canada's Orphan Works Regime: Unlocatable Copyright Owners and the Copyright Board' (2010) 10

(2) Oxford University Commonwealth Law Journal 215, 217.
} 


\section{Solution of orphan works under Canadian Copyright Act}

Canadian orphan works has adopted compulsory licensing. This solution is also known as non-exclusive licensing or centrally granted licenses. Under this model, users are able to make use of certain types of orphan work and licences are issued on a case-by-case basis by a competent authority. When an applicant is able to establish that he/she has conducted a diligent search to locate the copyright holder, but the copyright holder could not be located, then his/her application will be approved by a competent authority and he/she will be entitled to a non-exclusive conditional licence. ${ }^{1}$ Under this licence model, the potential user is required to deposit a royalty payment. ${ }^{2}$

\subsection{Scope of licences}

At the time section 77 was enacted in 1988, the Copyright Board of Canada was only authorised to grant licences for acts provided under section 3 of the Copyright Act, which entitles the copyright holder to produce, reproduce, translate, perform, record, convert, adapt, telecommunicate and display a work in public. ${ }^{3}$ After the legal system of the Canadian Copyright Board was broadened in 1997, it now has the power to issue licences for acts mentioned in sections 15, 18 and 21 of the Copyright Act, which deal with the rights of performers, sound recording makers and broadcasters, respectively. Therefore, section 77 of the Canadian Copyright Act is not only applicable to narrowly defined works, but also to performances, sound recordings and communication signals. ${ }^{4}$

In addition, regarding the purpose of the use, a licence can be issued irrespective of whether it is commercial, religious or educational. ${ }^{5}$ Furthermore, the licence can only be issued within the Canadian territory; outside that territory, the Board has no legal system to issue licences for making use of orphan works. However, the Board is entitled to issue licences regardless of whether the work is of domestic or foreign origin. ${ }^{6}$

\subsection{Terms and conditions of the issuance of licences}

There are various terms and conditions that should be met for the Copyright Board to issue a non-exclusive licence for the use of the orphan works in question. These terms and conditions are as follows.

\subsubsection{Published or fixed}

Under the Canadian Copyright Act, only published or fixed orphan works can be licensed, not unpublished or unfixed works, and there have been unsuccessful attempts to consider unpublished materials being licensed under an orphan works regime. ${ }^{7}$ However, allowing the granting of a licence only to published works is considered a deficiency of the system, due to the difficulty of establishing whether an old work, such as a photograph, has ever been published. Although this is a shortcoming of the system, it should be borne in mind that it respects the author's moral right to make the decision of whether or not to make his/her work accessible to the public. ${ }^{8}$ Moreover, in the case of granting a licence to make use of unpublished works, privacy rights issues can be raised. ${ }^{9}$

In addition, the Copyright Board of Canada has no legal system over works for which the publication status cannot be confirmed. Nevertheless, the Copyright Board has often presumed that a work has been published if decisive evidence is hard to come by but the circumstances indicate the likelihood of publication. ${ }^{10}$

\subsubsection{Subsistence of copyright}

In accordance with section 77(1) of the Canadian Copyright Act, the Canadian Copyright Board only has legal system over works, performances, sound recordings and communication signals which are still under copyright protection. ${ }^{11}$ By implication, the Copyright Board of Canada is not entitled to issue licences for the use of works in which copyright does not subsist. Works which do not meet the conditions for copyright protection are not safeguarded by copyright law and thus are implicitly omitted from the orphan works system. Likewise, the

\footnotetext{
${ }^{1}$ Brenda Siso-Calvo and others, 'Is There a Solution to the Orphan Works Problem? Exploring the International Models' (Transforming Digital Worlds 13th International Conference, Sheffield, UK, March 2018) available at $<$ https://link.springer.com/chapter/10.1007/978-3-319-78105$173>$ accessed 18 January 2019.

${ }^{2}$ Kelu L Sullivan, 'Orphan Works at the Dawn of Digitisation' (2012) 18 Richmond Journal of Law \& Technology 31.

${ }^{3}$ Canadian Copyright Act 1985 last amended on 19 June 2017, s. 3(1).

${ }^{4}$ Jeremy De Beer and Mario Bouchard, 'Canada's Orphan Works Regime: Unlocatable Copyright Owners and the Copyright Board' (2010) 10 (2) Oxford University Commonwealth Law Journal 215, 226.; Canadian Copyright Act 1985 last amended on 19 June 2017, ss. 15, 18, 21 and 77 .

${ }^{5}$ Stef van Gompel, 'The Orphan Works Chimera and How to Defeat It: A View from Across the Atlantic' (2012) 27 Berkeley Technology Law Journal 1347, 1369-1370.

${ }^{6}$ Stef van Gompel and P Bernt Hugenholtz, 'The Orphan Works Problem: The Copyright Conundrum of Digitizing Large-Scale Audiovisual, Archives, and How to Solve It' (2010) 4 The International Journal of Media and Culture 7.

${ }^{7}$ Peter B. Hirtle, 'Unpublished Material, New Technologies, and Copyright: Facilitating Scholarly Use' (2001) 49 Journal of the Copyright Society of the USA 9.

${ }^{8}$ Stef van Gompel, 'Unlocking the Potential Pre-existing Contents: How to Address the Issue of Orphan Works in Europe' (2007) 6 IIC 669, 689.

${ }^{9}$ Danilo Penetrante Ventajar, 'Finding a Home for Orphan Works: Will a Human Rights Perspective Help?' (Master Dissertation, Lund University 2010) 47.

${ }^{10}$ Stef van Gompel, 'The Orphan Works Chimera and How to Defeat It: A View from Across the Atlantic' (2012) 27 Berkeley Technology Law Journal 1347,1370

${ }^{11}$ Canadian Copyright Act 1985 last amended on 19 June 2017, s. 77(1).
} 
Copyright Board has no legal system to grant licences for making use of works for which copyright protection has expired..$^{1}$ I believe that the reason for excluding unprotected works from the orphan works regime is that those works can be freely used by anyone without having to obtain permission from the copyright owner.

Furthermore, it is debated whether the Copyright Board is entitled to issue a licence in situations in which it is not feasible to ascertain with certainty if a work is still under copyright protection. In those circumstances, it is preferred to issue a licence for the use of such works because the aim of designing an orphan works regime is to facilitate the use of copyrighted works and minimise the frustration of prospective users. ${ }^{2}$

Although the Canadian Copyright Board is not entitled to grant licences for the use of works for which copyright protection does not subsist, a slightly different question may arise here of whether the Copyright Board has legal system to issue licences for a non-infringing use of copyright-protected works. For instance, can the Copyright Board grant a licence for the use of an insubstantial part of a work? Section 77 of the Canadian Copyright Act enables the Copyright Board to issue a licence only with regard to acts mentioned in section 3, 15, 18 or 21 . Each of those sections mentions the concept of substantiality. Copyright holders have the right conferred upon them only to control the use of a substantial part of their work, performance, recording or signal. The utilisation of insubstantial parts is not referred to in the aforementioned sections. Implicitly, the Copyright Board has no power to grant licences respecting such uses. ${ }^{3}$

In addition, moral rights are deemed one of the most controversial issues in the Canadian Copyright Act because the title of the regime refers to 'owners who cannot be located', rather than orphan works. Therefore, it is argued that the Canadian system only emphasises copyright owners, not works or their authors. Furthermore, the Copyright Board only has the power to grant licences in respect of acts mentioned in section 3, 15, 18 or 21, but has no legal system over (at least not directly) the moral rights of authors, which are dealt with in section 14.1 of the Copyright Act. Nevertheless, there is a contrary argument which states that although section 77 does not expressly mention the moral rights of authors, a purposive interpretation of section 77 requires that the Copyright Board has legal system to tackle issues concerning an author's moral rights. Since it is believed that if the Copyright Board is only entitled to deal with economic rights, the solution under section 77 would be a partial one to the problem of orphan works. Finally, whether the Canadian parliament intended to provide a partial solution to the problem of orphan works, or purposefully addressed only economic rights, remains an open issue. ${ }^{4}$ I believe that the parliament intended to avoid some types of moral rights issues, if not all, because it expressly excludes unpublished works from the scope of section 77.

\subsubsection{Reasonable effort}

The Canadian Copyright Act requires the Copyright Board to be satisfied that the potential user has made reasonable efforts to locate the copyright holder before the Board grants a licence to the user. It is not a condition that the user shall make every effort to find the copyright holder, but the user is required to establish that he/she has carried out a thorough search. In order to conduct a thorough search, the Copyright Board's recommendation to prospective users is to contact various collecting societies and publishing houses; to consult indexes of national libraries, universities and museums; to check registration systems of copyright offices; to inspect inheritance records; and simply to search the internet. ${ }^{5}$

Furthermore, in the determination of the reasonableness of a search, the Copyright Board cooperates closely with other entities, such as the Canadian Copyright Licensing Agency and the COPIBEC ${ }^{6}$ collecting society. These entities help the Copyright Board examine applications for the utilisation of orphan works which are commonly found in their collections and advise the Copyright Board on the issuance of licences, licence royalties and other terms and conditions. ${ }^{7}$

Nevertheless, if the owner is located but refuses to negotiate or grant a licence, the Copyright Board will not issue a licence. Even if the copyright holder does not respond to any request from the user, the Copyright Board will not issue the licence as long as the copyright holder is locatable. ${ }^{8}$

\footnotetext{
${ }^{1}$ Jeremy De Beer and Mario Bouchard, 'Canada's Orphan Works Regime: Unlocatable Copyright Owners and the Copyright Board' (2010) 10 (2) Oxford University Commonwealth Law Journal 215, 222.

2 Jeremy De Beer and Mario Bouchard, 'Canada's Orphan Works Regime: Unlocatable Copyright Owners and the Copyright Board' (2010) 10 (2) Oxford University Commonwealth Law Journal 215, 222.

3 Jeremy De Beer and Mario Bouchard, 'Canada's Orphan Works Regime: Unlocatable Copyright Owners and the Copyright Board' (2010) 10 (2) Oxford University Commonwealth Law Journal 215, 222.

${ }^{4}$ Jeremy De Beer and Mario Bouchard, 'Canada's Orphan Works Regime: Unlocatable Copyright Owners and the Copyright Board' (2010) 10 (2) Oxford University Commonwealth Law Journal 215, 225.

${ }^{5}$ Stef van Gompel, 'Unlocking the Potential Pre-existing Contents: How to Address the Issue of Orphan Works in Europe' (2007) 6 IIC 669, 688 .

${ }^{6}$ COPIBEC is a collecting society in Canada and is the 'Société québécoise de gestion collective des droit de reproduction' (Quebec Society for the Collective Management of Reproduction Rights).

${ }^{7}$ Yael Lifshitz-Goldberg, 'Orphan Works' (WIPO Seminar, Hebrew University Jerusalem 2010) 7; Stef van Gompel, 'Unlocking the Potential Pre-existing Contents: How to Address the Issue of Orphan Works in Europe' (2007) 6 IIC 669, 688.

${ }^{8}$ Ariel Katz, 'The Orphans, the Market, and the Copyright Dogma: A Modest Solution for a Grand Problem' (2012) 27 Berkeley Technology Law Journal 1285, 1323
} 


\subsubsection{Payment of licence fees}

The Canadian Copyright Act is flexible regarding the payment of licence fees because the Copyright Board of Canada is vested with the right to oblige the prospective user to pay licence fees directly upon issuing a licence. The fee is then held in escrow for the missing copyright holder, or payment of the licensing fees may be postponed until the copyright owner resurfaces. ${ }^{1}$ If royalties are to be paid upon the issuance of a licence, the royalties are commonly held by a copyright collective society, which is usually the one that represents the copyright owner. ${ }^{2}$ The royalties paid by the user shall be reasonable and, in ascertaining what constitutes a reasonable royalty, the Copyright Board of Canada requires information from the prospective users respecting, if available, the amount of the licence fees in works licensed by the copyright holders themselves. It seems, however, that $\$ 25$ is, in practice, a default rule per use when no extra information is available. ${ }^{3}$

Moreover, the copyright holder is entitled to ask for paid royalties that were established at the time of authorisation if he/she reappears within five years from the time of the expiration of the licence. However, in the case that the royalties were not paid at the time the licence was issued and the user refused to pay them, the copyright holder is entitled to take the matter before a competent court to receive the required fees. ${ }^{4}$ Nonetheless, if the copyright holder does not reappear within five years from the date of the expiration of the licence, the royalty fee could be used for purposes other than those related to the use in question. The Canadian Copyright Board might instruct a collecting society, for instance, to use the undisbursed fees for the benefit of its members. ${ }^{5}$

1.2.5. Non-exclusivity

Section 77(2) of the Canadian Copyright Act only permits the Copyright Board of Canada to issue non-exclusive licences. ${ }^{6}$ This means that the user is not allowed to issue sub-licences and the user is bound to act within the frame of the licence.

\subsection{Discretion to set licence terms and conditions}

Once the Copyright Board is satisfied with regard to granting a licence, it will then make its decision on the appropriate terms and conditions of the licence. The terms and conditions are at the discretion of the Copyright Board, although there are some restrictions imposed by general legal principles and the Copyright Act. For instance, in accordance with section 77(2), the Copyright Board is only entitled to grant non-exclusive licences. This constraint seems to fulfil two objectives: firstly, it accounts for the possibility that an unlocatable owner may have issued (or may later issue) a licence to someone else; and secondly, it precludes the Copyright Board from granting what would amount to a monopoly on the utilisation of a specific orphan work. There are also other constraints on the discretion of the Copyright Board in setting the terms and conditions of a licence. The Copyright Board is required by the principles of administrative law to act fairly and its decisions should be supported by reasons. If the Copyright Board is compliant with the procedural and substantive requirements, it can impose reasonable terms and conditions as it deems appropriate. ${ }^{7}$

In imposing terms and conditions, the Copyright Board takes various factors into consideration. These factors might contain the number of copies requested, the level of predicted profit, the proposed use and the nature of the applicant. While taking the aforementioned factors into consideration, the Copyright Board determines licence terms and conditions on a case-by-case basis. ${ }^{8}$

\section{Advantages and disadvantages of the Canadian regime}

The Canadian orphan works regime has its own advantages and disadvantages. This chapter analyses such advantages and disadvantages.

\subsection{Advantages}

The main and salient advantage of the Canadian system is that it provides users of orphan works with adequate legal certainty. A licence granted by the Copyright Board of Canada guarantees users being able to use orphan works without fear of being liable for the infringement of copyright law in the case of a reappearing copyright

\footnotetext{
${ }^{1}$ Bernard Lang, 'Orphan Works and the Google Book Search Settlement: An International Perspective' (2010) 55 New York Law School Law Review 111, 129.

${ }^{2}$ Salvador M. Bezos, 'International Approaches to the Orphan Works Problem' (George Mason University 27 May 2007$)$ 13.

${ }^{3}$ Salvador M. Bezos, 'International Approaches to the Orphan Works Problem' (George Mason University 27 May 2007 ) 13.

${ }^{4}$ Joelle Farchy and Jessica Petrou, 'Optimising Use of Orphan Works While Respecting Intellectual Property Rights: A Law and Economics Perspective' (2012) 2 Queen Mary Journal of Intellectual Property 250, 262; Canadian Copyright Act 1985 last amended on 19 June 2017 , s. $77(3)$.

${ }^{5}$ British Screen Advisory Council, 'Copyright and Orphan Works: A Paper Prepared for the Gowers Review' (August 2006$) 32$.

${ }^{6}$ Canadian Copyright Act 1985 last amended on 19 June 2017, s. 77(2).

${ }^{7}$ Jeremy De Beer and Mario Bouchard, 'Canada's Orphan Works Regime: Unlocatable Copyright Owners and the Copyright Board' (2010) 10 (2) Oxford University Commonwealth Law Journal 215, 231.

${ }^{8}$ Jeremy De Beer and Mario Bouchard, 'Canada's Orphan Works Regime: Unlocatable Copyright Owners and the Copyright Board' (2010) 10

(2) Oxford University Commonwealth Law Journal 215, 231.
} 
holder. ${ }^{1}$ This model does not, meanwhile, unnecessarily compromise the lawful interests of the copyright holders concerned for a number of reasons. Firstly, verification of the user's good faith being carried out by an independent public body serves the needs of prospective users while taking the concerns of copyright owners into consideration. Secondly, licences are granted on a case-by-case basis, which results in avoiding disproportionate prejudice to the principle of exclusive rights that is inherent to the copyright system. Thirdly, the Copyright Board grants a licence to a particular user and for a specific use only. Finally, this model does not lead to the loss of income for copyright holders because copyright holders will be indemnified if they reappear. ${ }^{2}$

\subsection{Disadvantages}

Despite its advantages, the Canadian model has its own disadvantages. An often-claimed drawback is that the process of pre-clearance by a public body is time consuming and expensive. Although this disadvantage may be true to some extent, it should not be exaggerated because the Copyright Board of Canada shows that once it has received all the necessary information, a decision can usually be made within 30 to 45 days. Another disadvantage claimed by those who are opposed to the Canadian system is the small number of applications filed before the Copyright Board. However, other factors are involved in the relatively small number of applications, such as the restraints imposed on the Copyright Board to issue licences only within the territory of Canada. ${ }^{3}$

Legal and economic scholars have also criticised the Canadian system in stating that any system requiring pre-payment of licensing fees is likely to result in overpricing. They maintain that only after using an orphan work will the real value of the use be known and that fees ascertained on an ex ante basis cannot, by definition, be based on market licensing rates. ${ }^{4}$ Moreover, although the Copyright Act states that the Copyright Board shall be satisfied that the user has carried out reasonable searches to trace the copyright owner and, despite the search he/she has been unable to locate the copyright holder, the Act does not specify what is needed to satisfy the Copyright Board. Thus, it would be open to the Copyright Board to specify the threshold. ${ }^{5}$

In addition to economic inefficiency, a compulsory licensing model may not be possible for most libraries and non-profit orphan works users for various reasons. Firstly, licences under such a system are granted for a limited period of time and are unable to grant adequate security to cultural heritage institutions that seek to engage in long-term and very expensive digitisation of their whole collections. Secondly, a pre-paying licensing fee obligation is not fully commensurate with the cultural missions, limited resources and current clearance practices of many cultural institutions and libraries. Thirdly, a centrally granted licensing system is also criticised for being overly bureaucratic and expensive, as users under this system are required to carry out searches and are then reviewed by a central agency and the nature and ambit of the uses of orphan works authorised by the licences are documented. ${ }^{6}$

Finally, the Canadian system has been criticised for leaving unaddressed unpublished works and works whose publication status cannot be confirmed. Paying licensing fees to 'collective societies - which, no doubt, will in many cases be for works in the public domain - is in effect a tax' on the orphan works users that benefits members of society. ${ }^{7}$ Moreover, the Canadian Copyright Act only addresses works whose copyright holders are known but unlocatable; it does not deal with unknown copyright owners. ${ }^{8}$

\section{Conclusion}

This research studied the solution of orphan works under Canadian Copyright Act. It was concluded that Canada has adopted centrally granted licenses. There are two types of orphan works: those whose copyright holders are unidentified and those whose copyright holders are unlocatable. The research revealed that Canadian Copyright Act has only addressed the second type of orphan works, it does not deal with unknown copyright owners. Therefore, it would be more helpful to cover both types of orphan work.

It was found that the Canadian Copyright Act provides users of orphan works with adequate legal certainty, because a licence granted by the Copyright Board of Canada guarantees users being able to use orphan works without fear of being liable for the infringement of copyright law in the case of a reappearing copyright holder. However, it is claimed that this system does not work well, because of the small number of applications filed

\footnotetext{
${ }^{1}$ Stef van Gompel, 'Unlocking the Potential Pre-existing Contents: How to Address the Issue of Orphan Works in Europe' (2007) 6 IIC 669, 689.

${ }^{2}$ Stef van Gompel, 'The Orphan Works Chimera and How to Defeat It: A View from Across the Atlantic' (2012) 27 Berkeley Technology Law Journal 1347, 1372-1373.

${ }^{3}$ Stef van Gompel, 'Unlocking the Potential Pre-existing Contents: How to Address the Issue of Orphan Works in Europe' (2007) 6 IIC 669, 690.

${ }^{4}$ David R Hansen and others, 'Solving the Orphan Works Problem for the United States' (2013) 37 Colombia Journal of Law \& the Arts 1, 40.

${ }^{5}$ Ariel Katz, 'The Orphans, the Market, and the Copyright Dogma: A Modest Solution for a Grand Problem' (2012) 27 Berkeley Technology Law Journal 1285, 1324

${ }^{6}$ David R Hansen and others, 'Solving the Orphan Works Problem for the United States' (2013) 37 Colombia Journal of Law \& the Arts 1, 41.

7 Jerry Britto and Bridget Dooling, 'An Orphan Works Affirmative Defense to Copyright Infringement Actions' (2005) 12 Michigan Telecommunication and Technology Law Review 75, 106-107.

${ }^{8}$ Duke Law School, 'Orphan Works Analysis and Proposal' (Centre for the Study of the Public Domain, Duke Law School, March 2005$) 8$.
} 
before the Copyright Board. Moreover, a compulsory licensing model may not be possible for most libraries and non-profit orphan works users. The Canadian system has also been criticised for leaving unaddressed unpublished works and works whose publication status cannot be confirmed. Nevertheless, I believe that criticising the Canadian solution to orphan works for leaving unpublished works unaddressed is unfair, because licensing such works will be in conflict with the author's moral rights of first publication. Instead, I prefer to distinguish between two types of unpublished work: firstly, works that are only in the hands of the owner and no copy of the work is possessed by anyone; and secondly, works that are already in some publicly accessible collection, such in in archives and museums. A privacy issue can be raised regarding the first type of unpublished work; however, with regard to the second type of work, I cannot see that privacy is such a big issue because the privacy of the owner has already been revealed by some sort of means. Therefore, I believe that the Canadian model can only be criticised for not allowing the use of the second type of unpublished work under the orphan works regime.

\section{References}

1. Ahmed B and Al-Salihi K, 'Proliferation of the problem of orphan works across the world' (2019) 22 The Journal of World Intellectual Property 419.

2. Bezos S, 'International Approaches to the Orphan Works Problem' (George Mason University 27 May 2007) 13.

3. British Screen Advisory Council, 'Copyright and Orphan Works: A Paper Prepared for the Gowers Review' (August 2006).

4. Britto J and Dooling B, 'An Orphan Works Affirmative Defense to Copyright Infringement Actions' (2005) 12 Michigan Telecommunication and Technology Law Review 75.

5. Canadian Copyright Act 1985 last amended on 19 June 2017.

6. De Beer J and Bouchard M, 'Canada's Orphan Works Regime: Unlocatable Copyright Owners and the Copyright Board' (2010) 10 (2) Oxford University Commonwealth Law Journal 215.

7. Duke Law School, 'Orphan Works Analysis and Proposal' (Centre for the Study of the Public Domain, Duke Law School, March 2005).

8. Farchy J and Petrou J, 'Optimising Use of Orphan Works While Respecting Intellectual Property Rights: A Law and Economics Perspective’ (2012) 2 Queen Mary Journal of Intellectual Property 250.

9. Favale $\mathrm{M}$ and others, 'Copyright, and the Regulation of Orphan Works: A Comparative Review of Seven Jurisdictions and a Rights Clearance Simulation' (UK Intellectual Property Office, July 2013).

10. Golangelo G and Lincesso I, 'Law Versus Technology: Looking for a Solution to the Orphan Works' Problem' (2012) 20 International Journal of Law and Information Technology 178.

11. Goldberg Y, 'Orphan Works' (WIPO Seminar, Hebrew University Jerusalem 2010) 7.

12. Gompel S and Hugenholtz P, 'The Orphan Works Problem: The Copyright Conundrum of Digitizing LargeScale Audiovisual, Archives, and How to Solve It' (2010) 4 The International Journal of Media and Culture 7.

13. Gompel S, 'The Orphan Works Chimera and How to Defeat It: A View from Across the Atlantic' (2012) 27 Berkeley Technology Law Journal 1347.

14. Gompel S, 'Unlocking the Potential Pre-existing Contents: How to Address the Issue of Orphan Works in Europe' (2007) 6 IIC 669.

15. Hansen D and others, 'Solving the Orphan Works Problem for the United States' (2013) 37 Colombia Journal of Law \& the Arts 1 .

16. Hirtle P, 'Unpublished Material, New Technologies, and Copyright: Facilitating Scholarly Use' (2001) 49 Journal of the Copyright Society of the USA 9.

17. Katz A, 'The Orphans, the Market, and the Copyright Dogma: A Modest Solution for a Grand Problem' (2012) 27 Berkeley Technology Law Journal 1285.

18. Lang B, 'Orphan Works and the Google Book Search Settlement: An International Perspective' (2010) 55 New York Law School Law Review 111.

19. Lu B, 'The Orphan Works Copyright Issue: Suggestions for International Response' (2013) 60 Journal, Copyright Society of the USA 255.

20. Siso-Calvo B and others, 'Is There a Solution to the Orphan Works Problem? Exploring the International Models' (Transforming Digital Worlds 13th International Conference, Sheffield, UK, March 2018) $<$ https://link.springer.com/chapter/10.1007/978-3-319-78105-1 73> accessed 18 January 2019.

21. Sullivan K, 'Orphan Works at the Dawn of Digitisation' (2012) 18 Richmond Journal of Law \& Technology 31.

22. Ventajar D, 'Finding a Home for Orphan Works: Will a Human Rights Perspective Help?' (Master Dissertation, Lund University 2010). 